\title{
HOW DOES SCARCITY PROMOTION ELEVATE CONSUMER AGGRESSIVITY: AN EXPERIMENTAL STUDY CONDUCTED ON STUDENTS
}

\author{
Cynthia Ayu Manggarani,1 Shine Pintor Siolemba Patiro,2 Hendrian3 and Tri Astuti4 \\ ${ }^{1}$ Management Studies, STIE YKPN, J1. Seturan Raya, Yogyakarta, Indonesia \\ ${ }^{23}$ Management Studies, Universitas Terbuka, Pondok Cabe, Tangerang Selatan, Indonesia \\ ${ }^{4}$ Balai Litbang Teknologi Perbenihan Tanaman Hutan, Bogor, Indonesia \\ E-mail: cynthia.ayu@stieykpn.ac.id
}

\begin{abstract}
Marketers often apply the strategy of scarcity promotion to attract consumer attention to the company's product. However, this strategy often increases consumer's destructive, aggressive behaviors. A quantitative approach using the experimental method was thus conducted in this study to reveal the effect of advertisement exposure with scarcity promotion strategy on aggressive consumer response towards the product that the company offered. The results show that advertisements with a scarcity strategy expose one's perception that other consumers are perceived as threats. This perception arises since the probability of getting the product they want will be decreased when others are running after the same product. Theoretically, this condition will elevate the tendency of aggressive consumer behavior when attaining the product. Three studies with multiple behavioral measurements conducted on STIE YKPN students show destructive responses to the scarcity promotion applied by the company
\end{abstract}

Keywords: Scarcity; Aggressivity; Consumer Behaviour; Experiment

\section{PENGARUH PROMOSI KELANGKAAN PADA AGRESIFITAS KONSUMEN: SEBUAH STUDI EKSPERIMEN}

\begin{abstract}
ABSTRAK. Strategi pemasaran dengan menggunakan unsur kelangkaan untuk menarik perhatian konsumen seringkali diterapkan oleh perusahaan. Namun demikian, strategi ini telah terbukti menimbulkan perilaku agresif dan destruktif pada konsumen di berbagai negara. Di dalam penelitian ini kami melakukan studi eksperimen yang merupakan bagian dari pendekatan kuantitatif untuk mengungkap apakah memang benar strategi promosi kelangkaan dapat memantik perilaku agresif seseorang. Kami menggunakan paparan iklan barang langka, baik langka secara waktu maupun langka secara kuantitas, untuk membuktikan bahwa strategi kelangkaan memiliki pengaruh pada agresifitas konsumen. Hasil menunjukkan bahwa paparan iklan kelangkaan mampu meningkatkan persepsi seseorang untuk menganggap orang lain sebagai ancaman baginya dalam mendapatkan produk yang diinginkan. Tiga studi dengan pengukuran perilaku secara majemuk yang kami lakukan dalam penelitian ini, dengan menggunakan mahasiswa STIE YKPN sebagai partisipan dalam eksperimen. Hasil menunjukkan tanggapan destruktif terhadap strategi kelangkaan yang diterapkan oleh perusahaan.
\end{abstract}

Kata kunci: Kelangkaan; Agresifitas; Perilaku Konsumen; Eksperimen

\section{INTRODUCTION}

Humans will act aggressively and behave violently when the need for survival is limited (Griskevicius et al., 2009). Some reports show that similar behavior also occurs when a person is not in a situation where resources for survival are limited (Lynn, 1993). In other words, even when a person does not have any problems surviving, he or she will keep continuously being engaged in aggressive behavior.

Violent behavior is one form of triggering destructive culture that appears in the community. If it is considered reasonable, then such behavior can become a habit. Several studies have shown that the habit of seeing violent behavior in the environment can lead to bizarre parenting behavior in educating children (Udell et al., 2017), disruptive behavior in early childhood (Heberle et al., 2014), and difficulty in decision making in people adolescents stage
(Copping et al., 2013). It is necessary then to research the effect of scarcity goods promotion strategy on aggressive consumer behavior. Through the results of this study, marketers can avoid factors that are proven to encourage aggressive behavior and trigger consumer violent behavior.

Scarcity stems from an imbalance between demand and supply. Several factors that induce scarcity are usually in the form of economic recession (Griskevicius et al., 2013), the deficiency of water supplies (Hanasaki et al., 2013), food insecurity (Wutich et al., 2014), and the lack of residential land, which causes difficulties to survive for any person who faces it.

Surprisingly, when accommodation for life has been fulfilled, the phenomenon of scarcity still occurs. The scarcity of resources outside the primary resources needed to survive arises because of the unlimited human desires (Goovaerts, 2016). Among them is the desire to buy consumer goods (Ridgway 
et al., 2008). When the number or demanded product is above the number of products that the company can sell, then scarcity occurs. The scarcity of consumer goods can be caused by surging demand and delays or production (Lee and Jung, 2019).

On the other hand, the scarcity of manufactured goods can also be caused due to the marketer's intention. Marketers deliberately limit the availability of products in the market for promotion to increase sales (Goldsmith et al., 2016). The strategy of scarcity goods promotion is thus defined as marketing actions that emphasize the limited number of products in a market (Wright et al., 2012). Commonly, this marketing action is used for marketing a product for middle up to upper-class consumers because this group of consumers prefers goods that are not owned by most people (Pathak et al., 2017).

The scarcity level of a particular product can influence a consumer's perception of this product (Janssen et al., 2012). Consumers perceive a product to be more valuable when the amount of the product is limited (Koch and Benlian, 2015). This perception is highly dependent on consumer confidence level about the reasons behind the scarcity of the product.

When consumers do not have any information about a product, the consumer's intention to consume a limited number of products is greatly influenced by the people around them (Manggarani and Dharmmesta, 2018). Consumers consider a rare product worth more if the cause of scarcity is the popularity of the item (Wu and Lee, 2016). At the same time, consumers will consider a product less valuable when the cause of scarcity is the inability of companies to offer the availability of goods on the market (Foster et al., 2019).

Aggressiveness is the behavior of a person who has the effect of stimulating hostility, whether physically, verbally, or gesturally to another person (Tenenbaum et al., 1996). Several studies have shown a relationship between scarcity, competition, and aggressive behavior (e.g., Prediger et al., 2014; Miles-Novelo and Anderson, 2019).

However, aggressive behavior in the context of consumption may not only be caused by the scarcity of an item, but it can also be caused by a social impulse to carry out such behavior. Some aggressive behavior arises because someone considers the behavior to be reasonable (Sherif, 1936). For instance, in the event when people are willing to jostle to shop for holiday needs. In this case, although not rational, jostling to shop for holiday needs is considered normal. On the other hand, even though time and energy efficiency seems more rational, it is not natural to jostle shopping for holiday needs.
The implementation of scarce goods promotion as one of the company's marketing strategies has been mounting in almost every part of the world. Marketers are interested in using scarcity promotion strategy (Fowler, 2018) to create high sales rapidly (Parker and Lehman, 2011; Ku et al., 2012; Das et al., 2018). Yeezy Boost shoe collection from Adidas, Kaws T-shirt products from Uniqlo and Supreme clothing brands are several of those sought after by consumers who want an exclusive status when using these products (Upshaw et al., 2017).

However, although favored by marketers, the scarcity promotion, the company's scarcity has caused riots in several places (Jones, 2015; Freeman, 2019; Mantalean, 2019). The Black Friday Death Count website (2019) shows an increase in the number of victims from year to year due to annual promotions held by many companies in commemoration of Black Friday in the United States. In Indonesia, several crowds involving the promotion of scarcity promotion have also resulted in death toll (Ryandi, 2018).

Some companies often use various methods to achieve profits without paying attention to their impact on their surroundings. Adverse effects caused by the company can be in the form of material losses and non-material losses. A material loss, for example, is the loss or shrinking of the value of a property, while non-material loss can be in the form of a negative impact on the psychological condition or a decline in the personal quality of a person.

Furthermore, young people have always been an object of research interesting for researchers (Sara et al., 2018). Specifically, in this research, the youth population was chosen since they are very vulnerable to aggressive behavior. The aggressive behavior of young people is often influenced by the socioeconomic conditions in their daily environment (Fraser, 1996). They also often engage in immoral behavior (Gini et al., 2014). Thus, using the youth as the participants of this research is suitable to see whether scarcity promotion strategy will trigger aggressive behavior or not.

Referring to the background explained before, one of the psychological impacts caused by the marketing strategy of rare goods is aggressive traits that encourage violent behavior. Hence, it is critical to examine the conditions and reasons of how the scarcity promotion strategy could trigger aggressive behavior since the primary goal of marketing nowadays is to provide value for oneself and provide value for society in general.

This study aims to determine the underlying factors of consumer's aggressive behavior to emerge, and at the same time to determine the effect of scarcity goods promotion on aggressive behavior. Using an 
experimental method, researchers provide exposure to participants to disclose the effect of advertisements on their behavior. Furthermore, the results of this study will also show the impact of aggressive behavior on one's tendency to act violently. The hypotheses proposed in this research are as follow:

H1 : Consumers exposed by scarcity goods promotion strategy will act more aggressively than those who are not exposed by scarcity or promotion strategies.

H2 : Consumers exposed by scarcity goods promotion strategy will consider other consumers as threats for them more than those who are not exposed by scarcity goods promotion strategy.

H3 : The type of scarcity promotion strategy moderates the relationship between scarcity promotion strategy and aggressivity.

This research will expose whether consumers can behave aggressively even when they already in a state of a self-sufficient situation. This research also aims to test the assumption that consumer violence behavior often arises due to social influence from the community. While an aggressive nature triggers violent behavior, it cannot be separated from the influence of its marketing strategy.

\section{METHOD}

The method used in this research is a quantitative method employing experiments. The total number of participants for the entire study is 270. All subjects are university students from STIE YKPN Yogyakarta with the range of age 18-25 years old. The data analysis method used in this research were one-way ANOVA, and two-way ANOVA.

The research method begins with Study 1, which aims to test hypothesis 1 , whether consumers who are exposed to scarcity goods promotion strategy will act more aggressively compared to those who are not exposed by scarcity goods promotion strategy or not. In Study 1, exposure to advertising with a scarcity goods promotion is given to participants. At the same time, controlled exposure is advertising without scarcity goods promotion strategy. Since the display of aggressive behavior in a classroom setting is not possible, the researchers tested participants' aggressive behavior using violent themed video games (Anderson and Bushman, 2002).

50 STIE YKPN students are planned to participate in Study 1. These 50 people will be divided into two groups, each group consisting of 25 people to give two conditions (promotional ad: scarcity, control), manipulated between participants. The first group will be given advertising exposure with a scarcity of goods promotion strategy, while the second group will be given exposure to advertising without scarcity of goods promotion strategies. The ad in question is three leadership books authored by their lecturer sold at thirty thousand rupiahs (retail price is seventy-five thousand rupiahs). Participants are given the manipulation test question as follows, "What do you think the availability of promotional items provided by STIE YKPN?" Participants are asked to choose a number from a scale of 1 to 7.1 means very little, while seven is very abundant

In Study 2, we have two objectives. First, we seek direct evidence for the psychological processes underlying the increase in aggressive behavior in response to the promotion of scarcity. We predict that the promotion strategy of limited quantity scarcity can encourage individuals to perceive other consumers as a potential threat in obtaining the desired product (hypothesis 2). We make this increased threat as the assumption that feelings of being threatened can mediate the relationship between the promotion of scarcity and aggressive action (hypothesis 3 ).

A total of 100 STIE YKPN students participated in Study 2 and were randomly divided into two groups of participants (promotional ad: scarcity vs. control). When present at the lab, participants are given information that they will be asked to complete several unrelated studies. First, participants were asked to provide feedback for the promotion of the campus library, which will be launched shortly. The instructions given in Study 2 were the same as the instructions given in Study 1 because the exposure to advertisements for rare items was similar. What is different, in Study 2, the games played were in the form of a boxing game called Face Breaker using the Wii console.

While in Study 3, we intend to support our claim that the type of scarcity promotion strategy can influence consumers' perceptions of the perceived threat of other consumers. Marketers often use two types of promotional strategies for rare goods, namely quantity, and time-based promotion strategies. Suppose the promotion of the quantity-based rare goods strategy highlights the limited number of items that consumers can buy, then promoting the timebased rare goods strategy. Consumers can only buy these items within a certain period (for example: only available today and only available until noon).

120 students from STIE YKPN Yogyakarta. $M_{\text {age }}=20.3,50.9 \%$ female) STIE YKPN Yogyakarta participated in Study 3. They are randomly assigned to work on one of five conditions in 2 (promotional ad: scarcity, control) x 2 (scarcity type: quantity, time) + (control-information omitted) between-participant 
design. Participants were asked to play shooting games as in Study 1.

Furthermore, in Study 3, we want to clarify the constructs of aggressive and non-aggressive responses caused by the promotion of rare goods by including the dependent measures of both. Specifically, we provide additional tasks forparticipants to complete competitive word-guessing games that are not aggressive or nonviolent. If both types of promotion of rare goods can be generalized, then the level of consumer competition in these two types of promotions should be the same. However, referring to the theory we have assumed, we stick to the dogma that quantity-based rare goods promotion strategies will dominate the increasing influence on aggressive consumer behavior compared to time-based rare goods promotion strategies. After receiving the advertisement exposure, participants were asked to answer questions to check for scarcity manipulation as follows, "What do you think about the availability of reference book products?" Participants were given an answer scale of 1 (very rare) to 7 (very abundant).

Study 3 also uses controlled variables in Study 2 , namely promotion without scarcity strategies based on quantity or time. Controlled variables were used to confirm that the increase in aggressiveness resulted from a promotion strategy for rare goods, not the other way around (abundance of products offered). Participants exposed to the quantity-based promotion of rare goods advertising were more aggressive than those exposed to controlled advertising. However, we also hope no difference in aggressive behavior between participants exposed to time-based rare goods promotion strategies and participants exposed to controlled ads.

In contrast to Study 1, in Study 3, we modified the game into two types, namely aggressive games and non-aggressive games. To measure aggressive behavior, we used Deadeye's game in Study 1, which used the number of shots to measure aggressive behavior. Meanwhile, to measure non-aggressive competitive behavior, we used a game of wording speed at an advanced difficulty level.

Participants are given instructions to complete the wording game within 1 minute, and the number of words completed will be used as a dependent measure of the participant's non-aggressive behavior. The score in each type of game was calculated by coders who knew nothing about the hypothesis in this study.

\section{RESULTS AND DISCUSSIONS}

Through the two studies we gave to participants, we demonstrated how effective the promotion of rare goods could be on consumer aggressiveness. We have proposed a framework for understanding the processes underlying when and why consumers engage in violent acts and when the scarcity of promoting rare goods does not lead to aggressive behavior.

In study 1, we found that consumers exposed to the promotion of rare goods would behave more aggressively than consumers who were exposed to controlled promotions, which offered the same product but without a description of the number of products available. We also found that participants exposed to the promotion of rare goods appeared to release a higher number of bullets than those exposed to controlled promotion through shooting behavior.

The manipulation check results in Study 1 show that the manipulation of the rarities that the researcher has provided is successful. Participants perceive that researchers' quantity-based promotions indicate the scarcity of products offered by the company. Thus, scarcity occurs in rare conditions compared to controlled conditions $\left(\mathrm{M}_{\text {Scarcity }}=1.72 \mathrm{vs}\right.$. $\left.\mathrm{M}_{\text {Control }}=3.97 ; F(1,138)=68.5, p<.001\right)$.

Meanwhile, the number of bullets fired by the participants in Study 1 showed abnormal results $(\Upsilon$ Shots Fired $=2.48, \omega(140)=.72, \mathrm{p}<.001)$; so that to test this hypothesis, the researcher must perform a log-transformed procedure. Even so, the results still show consistency when processed using raw values. Therefore, researchers still report the mean raw score and standard deviation to facilitate readers' understanding. Researchers tested the shooting behavior of the participants with one-way ANOVA and used the number of shots as the dependent variable. As predicted previously, participants exposed to a rare item promotion strategy shot more bullets than participants given the control promotion. $($ MScarcity $=42.3, \mathrm{SD}=19.4$ vs. $\mathrm{MControl}=37.0$, $\mathrm{SD}=11.7 ; \mathrm{F}(1,138)=4.02, \mathrm{p}=.047)$.

Study 1 provides initial support for the hypothesis that exposure to limited quantity promotions can increase aggressive consumer behavior (Hypothesis 1). The findings show that consumers behave more aggressively when given exposure to rare promotional items, products they like. The critical point, this result also shows that the participants' aggressive behavior arises due to the promotion of scarcity of products that are not urgent (reference books) to middle and upperclass participants (STIE YKPN campus students). It suggests that participants not only act aggressively when faced with a survival situation, but this behavior can also appear in other consumption contexts.

Study 2 shows support for our claim that aggressive behavior is driven by the perception that other people are a threat to someone in obtaining 
goods in a given promotion. Using boxing games as a measure of aggressive behavior, researchers found that advertising promotions with a rare-goods strategy did encourage consumers to perceive others as a threat when one wants to get a limited product. The more the other person is perceived as a threat, the greater the number of punches the inner participant provides at the non-counterattacking target.

The manipulation check results in Study 2 show that the manipulation of the rarities that the researcher has provided is successful. Participants perceive that researchers' quantity-based promotions indicate the scarcity of products offered by the company. Thus, scarcity occurs in rare conditions compared to controlled conditions $\left(M_{\text {Scarcity }}=1.72 \mathrm{vs.}\right.$ $\left.M_{\text {Control }}=3.97 ; F(1,138)=68.5, p<.001\right)$.

The results show support for hypothesis 2 which states that participants tend to give more reviews of boxing targets after being given exposure to rare goods promotions than after being given controlled promotions $\left(M_{\text {Scarcity }}=42.3, \mathrm{SD}=19.4\right.$ vs. $M_{\text {Control }}=$ $37.0, \mathrm{SD}=11.7 ; F(1,138)=4.02, p=.047)$. In testing the indirect effect, we used a bootstrap procedure (Preacher et al., 2007), replacing a total of 10,000 samples. Participants who are given exposure to rare goods promotion strategies will build the perception that other consumers threaten them in getting the products they want. This level of perception was higher in those exposed to rare goods promotion strategies than those exposed to controlled promotions $\left(M_{\mathrm{S}}\right.$ $=42.3, \mathrm{SD}=19.4$ vs. $M_{\text {Control }}=37.0, \mathrm{SD}=11.7 ; F(1$, $138)=4.02, p=.047)$. Next, to control for the rarity condition, we used the number of views as a predictor of perceived threat $(b=3.86, t(104)=2.23, p=.028)$. These results support hypothesis 2 , which states that perceived threat is an intermediary for the relationship between the promotion strategy of rare goods and aggressive consumer behavior.

The results of Study 2 support our research framework, which suggests that exposure to quantitybased scarcity promotion can lead to more aggressive behavior. Besides, we extend the findings of previous studies in two ways. First, we show support for the finding that the perceived threat of the presence of others arises in order to achieve desired goals. These findings support hypothesis 2 , which states that quantity-based promotion strategies for rare goods can increase consumer perceptions that other people threaten them. Thus, this threat perception mediates the relationship between the quantity-based promotion of rare goods and aggressive consumer behavior.

Furthermore, in Study 2, we explored another type of violence in aggression with the closest proxy to aggressive behavior in the real world. We found that people exposed to quantity-based rare goods promotion strategies acted more aggressively by punching a more significant number of human-like targets than those not exposed to quantity-based promotions of rare goods.

Two types of manipulation checks in Study 3 indicate that the manipulations applied in this study follow the researcher's objectives. Participants exposed to advertisements with quantity-based promotion strategies for rare goods had significantly perceived that the goods offered by the company were rarer than the perceptions received by the participants under controlled conditions. ( $M_{\text {Limited-Quantity }}=1.76, \mathrm{SD}$ $=1.34$ vs $M_{\text {Control-Quantity }}=4.00, \mathrm{SD}=1.61, F(1,130)=$ $38.4, p<.001)$.

Participants who were given exposure to the promotion of rare goods based on time also perceived that the goods offered by the company were rarer than those who were given exposure to the promotion of rare goods under controlled conditions. $\left(M_{\text {Limited-Time }}=\right.$ $3.00, \mathrm{SD}=1.94$ vs $M_{\text {Control-Time }}=4.83, \mathrm{SD}=1.85, F$ $(1,136)=17.3, p<.001)$.

Participants exposed to time-based rare goods promotion advertisements also perceived that we predict that rare goods promotion can moderate the relationship between rare goods promotion strategies and aggressive behavior. In a previous study, the results indicated that the number of shots was abnormal in that the goods offered by the company were rarer than those exposed to the promotion of rare goods under controlled conditions. ( $\Upsilon$ Shots Fired $=2.48, \omega(140)=.72, p<.001)$, so it needs to be log-transformed. We contrast-coded the two conditions of scarcity $(-1=$ scarcity,$+1=$ controlled $)$ and scarcity type $(-1=$ quantity, $+1=$ time $)$ on the dependent variable, and using the $2 \times 2$ ANOVA method to predict aggressive behavior.

The results show the value of $p>.95$, which means that actually there is no effect originating from the scarcity condition, the main effect arises from the type of scarcity promotion used $\left(M_{\text {Quantity }}=33.0\right.$, $\mathrm{SD}=5.37$ vs $M_{\text {Time }}=30.5, \mathrm{SD}=5.75, F(1,130)=$ $5.18, p<.025)$. However, this main effect does meet the conditions for predicting a two-way interaction $(\mathrm{F}(1,130)=8.37, \mathrm{p}=.004)$. This study also shows support for hypothesis 3, which states that the type of scarcity promotion moderates the relationship between scarcity promotion strategies and aggressive behavior, especially scarcity promotion will affect increasing aggressive behavior when the type of promotion of rare goods used is quantity-based, not time-based.

Participants exposed to quantity-based rare goods promotion strategies launched more shots than 
participants exposed to controlled quantity-based

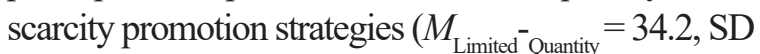
$=6.28$ vs $M_{\text {Control-Quality }}=31.8, \mathrm{SD}=3.85, F(1,130)=$ $4.69, p<.032)$. However, the results show that the same is not the case for participants exposed to time-based rare goods promotion strategies. Participants exposed to a time-based rare item promotion strategy fired more shots than participants exposed to controlled quantitybased promotional advertising. These results indicate that a time-based rare goods promotion strategy may cause a decrease in participants' perceptions of threats from other parties in obtaining the desired goods. Thus, participants assume that a decrease in threat results in a lower level of need to act aggressively. To make it more certain that aggressive behavior resulted from the large number of shots being fired on a quantity-based rare goods promotion strategy, we compared it to an uninformed controlled promotion strategy. As a result, participants exposed to quantity-based promotional strategies shot more bullets than participants exposed to controlled advertisements without information

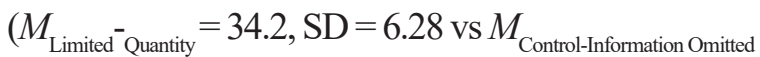
$=31.6, \mathrm{SD}=7.67, F(1,147)=4.08, p<.04)$.

Lastly, study 3 is intended to support our claim that the type of scarcity promotion strategy can influence consumers' perceptions of threat towards other consumers. Through study 3 , it is proven that aggressive behavior occurs when participants are exposed to quantity-based rare goods promotion strategies, not time-based rare goods promotion strategies.

\section{CONCLUSION}

Through this article, we expect that policymakers will finally understand the adverse effects of the company's rare goods promotion strategy. This research can be used as a reference for policymakers to make regulations regarding marketing tactics to protect consumer welfare. Some of the policies include fulfilling the proper employee-consumer ratios, the number of security forces in stores when promotions occur, or directly managing promotional content for rare goods using the basis of the findings in this article. Thus, the safety of consumers, store employees, and the wider community can be guaranteed.

\section{REFERENCES}

Black Friday Death Count. (n.d.). Retrieved from http://blackfridaydeathcount.com/

Copping, L. T., Campbell, A., \& Muncer, S. (2013). Violence, Teenage Pregnancy, and Life History: Ecological Factors and Their Impact on Strategy-Driven Behavior. Human Nature, 24(2), 137-157.

Das, G., Mukherjee, A., \& Smith, R. J. (2018). The Perfect Fit: The Moderating Role of Selling Cues on Hedonic and Utilitarian Product Types. Journal of Retailing, 94(2), 203-216.

Fraser, M. W. (1996). Aggressive Behavior in Childhood and Early Adolescence: An Ecological-Developmental Perspective on Youth Violence. Social Work, 41(4), 347-361.

Freeman, N. (2019). KAWS Dropped His New Line of Clothes for Uniqlo-Chaos Ensued. Downloaded from https://www.artsy.net/ news/artsy-editorial-kaws-dropped-newclothes-uniqlo-chaos-ensued on 7 July 2019.

Foster, J., Deck, C., \& Farmer, A. (2019). Behavioral Demand Effects when Buyers Anticipate Inventory Shortages. European Journal of Operational Research, 276(1), 217-234.

Fowler, D. (2018). The Hype Machine: Streetwear and the Business of Scarcity. Downloaded from https://www.bbc.com/worklife/ article/20180205-the-hype-machine-streetwearand-the-business-of-scarcity on 20 July 2019.

Gini, G., Pozzoli, T., \& Hymel, S. (2014). Moral Disengagement among Children and Youth: A Meta-Analytic Review of Links to Aggressive Behavior. Aggressive Behavior, 40(1), 56-68.

Goldsmith, K., Hmurovic, J., \& Lamberton, C. (2016). When Exploding Deals Create Competitive Customers: Understanding the Psychological Consequences of Scarcity Marketing Tactics. Advances in Consumer Research, 44, 476.

Goovaerts, D. (2016). Verizon's “Unlimited” Problem: Why Consumers Want What Doesn't Exist. Wireless Week.

Griskevicius, V., Tybur, J. M., Gangestad, S. W., Perea, E. F., Shapiro, J. R., \& Kenrick, D. T. (2009). Aggress to Impress: Hostility as an Evolved Context-Dependent Strategy. Journal of Personality and Social Psychology, 96(5), 980-994.

Griskevicius, V., Ackerman, J. M., Cantú, S. M., Delton, A. W., Robertson, T. E., Simpson, J. A., Tybur, J. M. (2013). When the Economy Falters, Do People Spend or Save? Responses to Resource Scarcity Depend on Childhood Environments. Psychological Science, 24(2), 197-205. 
Hanasaki, N., Fujimori, S., Yamamoto, T., Yoshikawa, S., Masaki, Y., Hijioka, Y., Kanae, S. (2013). A Global Water Scarcity Assessment Under Shared Socio-Economic Pathways -- part 2: Water Availability and Scarcity. Hydrology and Earth System Sciences, 17(7), 2393-2413.

Heberle, A. E., Thomas, Y. M., Wagmiller, R. L., Briggs-Gowan, M. J., \& Carter, A. S. (2014). The Impact of Neighborhood, Family, and Individual Risk Factors on Toddlers' Disruptive Behavior. Child Development, 85(5), 2046-2061.

Janssen, C., Vanhamme, J., Lindgreen, A., \& Lefebvre, C. (2012). Sustainable Luxury: Oxymoron or Pleonasm? How Scarcity and Ephemerality Affect Consumers' Perception of Fit Between Luxury and Sustainability. Advances in Consumer Research, 40, 1125.

Jones, R. (2015). Chaos Erupts in Europe As Lines Swell Over the Yeezy Boost Release. Downloaded from https://www.complex. com/sneakers/2015/03/paris-yeezy-boostrelease on 20 July 2019.

Koch, O. F., \& Benlian, A. (2015). Promotional Tactics for Online Viral Marketing Campaigns: How Scarcity and Personalization Affect Seed Stage Referrals. Journal of Interactive Marketing, 32, 37-52.

Lee, S. Y., \& Jung, S. (2019). Shelf-Based Scarcity and Consumers' Product Choice: The Role of Scarcity Disconfirmation. Social Behavior and Personality: An International Journal, 47(5), 1-10.

Lynn, M. (1993). The Psychology of Unavailability: Explaining Scarcity and Cost Effect on Value. Journal of Marketing Research, 30(3), 395-398.

Manggarani, C. A., \& Dharmmesta, B. S. (2018). Trying to Buy a New Product: What does Advertising do Nowadays? Asia Pacific Journal of Advanced Business and Social Studies, 4(1), 352-362.

Mantalean, V. 2019. Cerita Serbuan Pembeli Uniqlo x KAWS di Senayan City, Antre Sejak Pagi hingga Menangis Tak Kebagian. Downloaded from https:/megapolitan.kompas.com/ $\mathrm{read} / 2019 / 06 / 07 / 14383331 /$ cerita-serbuanpembeli-uniqlo-x-kaws-di-senayan-city-antresejak-pagi?page=all on 25 July 2019.

Miles-Novelo,A., \& Anderson, C. A. (2019). Climate Change and Psychology: Effects of Rapid
Global Warming on Violence and Aggression. Current Climate Change Reports, 5(1), 36-46.

Parker, J. R., \& Lehmann, D. R. (2011). When ShelfBased Scarcity Impacts Consumer Preferences. Journal of Retailing, 87(2), 142-155.

Pathak, A., Calvert, G., \& Velasco, C. (2017). Evaluating the Impact of Early and LateAcquired Phonemes on the Luxury Appeal of Brand Names. Journal of Brand Management, 24(6), 522-545.

Prediger, S., Vollan, B., \& Herrmann, B. (2014). Resource Scarcity and Antisocial Behavior. Journal of Public Economics, 119, 1-9.

Ridgway, N., Kukar-Kinney, M., \& Monroe, K. (2008). An Expanded Conceptualization and A New Measure of Compulsive Buying. Journal of Consumer Research, 35(4), 622-639.

Ryandi, D. (2018). Bocah 10 Tahun Tewas Karena Sembako Maut di Monas, Ini Kronologisnya. Downloaded from https:/www.jawapos. com/metro/metropolitan/02/05/2018/bocah10-tahun-tewas-karena-sembako-maut-dimonas-ini-kronologisnya/ on 29 July 2019.

Sara, A., Elena, Z., Valentina, S., Marta, E., Dania, C., Giancarlo, C., Pozzi, M. (2018). Knowledge, Motivations and Barriers Regarding Blood Donation among Students in Different Undergraduate Majors. American Journal of Applied Sciences, 15(9), 432-442.

Sherif, M. (1936). The Psychology of Social Norms, New York: Harper.

Tenenbaum, G., Stewart, E., Singer, R. N., \& Duda, J. (1996). Aggression and Violence in Sport: An ISSP Position Stand. International Journal of Sport Psychology, 27, 229-236.

Udell,W.A.,Hotton,A.L., Emerson,E.,\&Donenberg, G. R. (2017). Does Parental Monitoring Moderate the Impact of Community Violence Exposure on Probation Youth's Substance Use and Sexual Risk Behavior? Journal of Child and Family Studies, 26(9), 2556-2563.

Upshaw, D., Amyx, D., \& Hardy, M. (2017). The Nature of Exclusivity. Journal of Marketing Development and Competitiveness, 11(2), 46-63.

Wright, S., Hernandez, J. M. C., Sundar, A., Dinsmore, J., \& Kardes, F. (2012). Effects of Set Size, Scarcity, Packaging, and Taste on the Marketing Placebo Effect. Advances in Consumer Research, 40, 917-919. 
Wu, L., \& Lee, C. (2016). Limited Edition for Me and Best Seller for You: The Impact of Scarcity versus Popularity Cues on Self versus OtherPurchase Behavior. Journal of Retailing, 92(4), 486-499.
Wutich, A., \& Brewis, A. (2014). Food, water, and scarcity: Toward a broader anthropology of resource insecurity. Current Anthropology, 55(4), 444-468. 